\title{
SOBRAL AND ITS HARD-EARNED SUCCESS IN THE INTERNATIONAL COSTUME JEWELRY MARKET
}

Mila VianA - mila.viana@globo.com

Pontifícia Universidade Católica do Rio de Janeiro, Rio de Janeiro - RJ, Brasil

JORGE CARNEIRo - jorgemtc@iag.puc-rio.br

Pontifícia Universidade Católica do Rio de Janeiro, Rio de Janeiro - RJ, Brasil

MARCOS GARRIDO - mgarridobr@gmail.com

Pontifícia Universidade Católica do Rio de Janeiro, Rio de Janeiro - RJ, Brasil

Tania Peixoto - tania.px@gmail.com

Pontifícia Universidade Católica do Rio de Janeiro, Rio de Janeiro - RJ, Brasil

The story of Carlos Alberto Sobral is inextricably bound up with that of his company. As a teenager, he already had an affinity for the arts, mathematics and history. An idealist by nature, he began his professional activities in the late 1960s in the town of Saquarema, in the state of Rio de Janeiro, Brazil, where he had gone to live in a hippy commune, making and peddling handcrafts outside bars. He lived from one day to the next, with no planning whatsoever. His goods included sandals made from scrap tires, "Moroccan bags" (which, he explains, had nothing to do with Morocco, but were just due to the fact that maroquinier means bag maker in French) and the seemingly inevitable costume jewelry. In Região dos Lagos, along the northern coast of Rio de Janeiro, some Argentinian artisans introduced Sobral to resin - a raw material, that was then virtually unknown in Brazil's costume jewelry business. Sobral was delighted with the material and realized that if he used it, it would really set his own handicraft apart. He carried out some research and found a manufacturer in Rio de Janeiro (Indústria Resana), which worked in the marine industry. There he learned about the composition of resin and other technical features of the material, as well as how to handle it and the chemical process involved in producing it. Later in 1978, when he opened his factory, Sobral ceased to use other materials such as leather and metal. His hunch was right: it was with resin that Sobral, years later, would penetrate the major international markets.

Today, Sobral insists his story is not so much a series of successes, but rather one of failures combined with perseverance. Since his first company, Genesis, was founded in 1978, Sobral has started and closed down many companies. However, he never gave up, since he was driven by the need to support his family and the conviction that he could pursue his artistic ambitions through 
costume jewelry. He would absorb technical know-how to improve production and learn from previous administrative experience, always avoiding repeating the mistakes of his most recent failure. His aim was to constantly improve and learn more, by replicating earlier successes in his new ventures.

The original factory was where Sobral took client orders, mainly from famous brand names of accessory companies whom Sobral supplied with products - from design to manufacture, with the end- product bearing the client's brand. At that time, although Sobral believed he had mastered all the techniques of working with resin, he was, in fact, still learning. He also believed he could introduce revolutionary management and administration skills and dreamed of building a more human company without a hierarchical structure.

Today, Sobral states that his greatest challenge is to remain competitive in the domestic market - despite being faced with a heavy tax burden in Brazil - and also compete in the international markets - where Chinese firms have been trying hard to gain a foothold.

While Brazil still represents a very significant source of income and profit, Sobral knows that he must keep expanding abroad, not only because of the potential profits out there, but also because having an international presence can help consolidate his brand name among Brazilian customers. However, constraints in resources (financial, labor and managerial alike), together with the need to choose new countries very carefully, and doubts about the best operational strategy to employ abroad, are keeping Sobral anxious and tense.

\section{The first steps towards increasing foreign markets}

By the early 1980s, Sobral realized that, since he was unknown to the public, he could never sell costume jewelry directly on a large scale. High volume sales would only be possible through major retailers. On his own admission, Sobral had agreed to become a "ghost" designer - by abandoning creativity to produce costume jewelry pieces for the collections of major national retailers.

As time went by, Sobral continued to perfect his production techniques based on resin, and he and his ex-wife gradually began to make the designs and models themselves, thus taking back control of the creative process. At this time, he decided to engage in a large- scale production of a line of white, pearl and transparent bracelets - since these kinds of bracelets were the height of fashion. The colors were chosen because they are easy to dye, and this allowed almost immediate delivery to clients in Brazil. However, the fashion for bracelets died down and as a result, orders for items fell to almost zero. Owing to a high turnover, the stockpile of bracelets had reached a very high level. The question was what to do with 700,000 surplus items.

Sobral decided to solve this problem by "going international", something he had been planning on doing for some time. In 1981, without a plan or any type of network, he decided to try his luck in Europe, and left for Paris with a suitcase full of bracelets - which were part of the unsold stock of 700,000 pieces that Sobral had kept as he waited for some opportunity to try to put them back in the market. His idea was to sell them wholesale on the streets of the French capital - where today he has two stores selling the Sobral brand. However, this venture ended in failure and Sobral realized he would not be able to sell his huge stock of bracelets; at the same time, he noted that there was a market for other products. Sobral also realized that he had inadvertently run great risks, since he was in the country illegally and had no retail license that would permit him to sell his products there. 
Hence he returned to Brazil, where he produced some other items for the French market, and returned the following year to gauge receptivity in this much sought after market. In an exploratory frame of mind, Sobral entered a store in Paris, Marc Labat Diffusion, and met the owner, Marc Labat who, by chance, spoke good Portuguese. He had opened his store not long before as a wholesaler of costume jewelry. Sobral and Labat soon realized that they could cooperate and make progress in this market. This acquaintance was crucial for Sobral, since Labat was familiar with the intricacies and legal procedures of the French business environment - and he spoke Sobral's native language too!

Thus, in 1982 Sobral made his first legal international sales, and exports expanded at a faster rate after 1983. That year, the volume of exports to distributors of famous international brands, including Valentino, Gucci, Chanel, among others exceeded BRL 1 million. Exports and partnerships with distributors were vital to enable Sobral's art to become known in the world's most important fashion market. Paris is undeniably the capital of fashion, and he always believed that if his products were accepted in this highly demanding market, new doors to other markets would naturally be opened. Once the French market was conquered, everything would be easier.

The partnership with Labat was very important for the first steps of Sobral in foreign lands. Labat opened the doors of the French market to Sobral. The partnership went on for some years, until Sobral felt confident enough to stand on his own legs. When Sobral opened his first store in Paris, in 1991, the partnership with Labat came to an end.

His wave of success, however, was interrupted in the 1990s when there was a flood of Chinese products on the international market, at extremely competitive prices, and this caused Sobral to lose much of the ground he had won thus far. The Chinese competition forced him to rethink how he could keep his products in the international market. Sobral eventually decided that the best way to position his brand and protect himself from the predatory price competition of the new entrants in the international market was to open his own small store in Paris. The strategy worked: his own items were different - both the materials and the design - and his own products had a soul and artistic merit. Sobral says he learned an important lesson about the fashion market from Iesa Rodrigues, a journalist specializing in the business: "Fashion is what changes: if it doesn't change, it's not fashion".

As experts say, fashion tends to bounce back years later; it is cyclical, but always prepared to adapt to new concepts that emerge. Twenty years later, in 2002, to be precise, fashion bracelets came back with a vengeance. Sobral had kept the stock of 700,000 white, pearl and transparent items, and it was enough to adapt them to the colors and prints of the latest fashion and sell them in the Brazilian and international markets. The same stock of bracelets, which hitherto had caused him such a headache, became one of the reasons for his success, and funded a new cycle of business growth twenty years later.

During the first decade of this Century, Sobral opened up two stores in Paris and one in Heidelberg, Germany. In October 2009, he opened up his first store in New York's Soho district, with major international brands as neighbors, including Dona Karan, Calvin Klein, Louis Vuitton, etc. Large-scale production gave way to small-batch production, which was always in tune with the international fashion market and followed the rapid changes in fashion that govern this market sector. The company began structuring itself and implementing corporate practices to compete with the major players in Brazil and abroad.

Sobral says that with every new foray in the business world, it seemed that each project had lasted longer than the previous one, and that his experience consisted of a series of alternating 
successes and failures; yet all these attempts had contributed to the current success of his company. However, he says he is always on the alert, because experience shows that success can be short-lived. Having said this, should the need arise, Sobral claims that he is ready for the next venture - and this is a part of what he explains is a natural process in his life as a professional.

\section{The costume jewelry sector}

Although Brazil was already a well-known international competitor in commodities exports, it was only after 1990 that the country reached its highest level globally, in macroeconomic terms, and there was a greater diversification of its product portfolio and a considerable growth in exports and imports ${ }^{1}$.

From pre-historic times to the present day, a very wide range of ornaments has been used to embellish, to distinguish, and to conquer. The market for gems, fine jewelry and costume jewelry continues to grow. Costume jewelry is synonymous with alternative accessories, and made of different materials such as plastic, wood, stone, resin, brass, seeds and bamboo, i.e. non-precious materials. But when crafted with a certain deftness, the creative designs won over all kinds of audiences. In recent years, costume rings, necklaces, earrings and bangles have become entrenched in the market as fashion accessories and led to sales worth millions of dollars in Brazil.

"The costume jewelry market has always existed and will continue to exist - with or without the crisis - for the simple reason that consumers have a strong emotional connection to the pieces", says Vera Masi, head of Mais \& Associados, which organizes Bijóias, one of Brazil's largest costume jewelry trade shows. "Moreover, they are cheap and attractive products, even with Brazil's increased costs", she adds. The business does not require a large investment, machinery, or sophisticated technology. It depends on creativity and design. In the case of assembled costume jewelry, i.e. using alternative materials (fabrics, straw, pebbles, glass), annual sales were BRL 45 million in 2002. With regard to pieces gilded with silver or gold, which are also included in this category, the business was worth BRL 55 million². Most of the costume jewelry market, however, uses resin as the main material. SIDDA, a trade fair in Italy where the new trends in the use of materials are often set, is the leading global benchmark with respect to resin technology and processing.

Success in business can be seen as the entrepreneur's ability to follow trends and exploit several sales channels. "Whoever comes out ahead at this moment gets the best deals", adds Masi. Yet after manufacturing, we have to show the pieces to the customers. "Entrepreneurs, especially first-time entrepreneurs, forget to tie sales to production", notes Silva, a consultant to the jewelry market $^{3}$. The table in Exhibit 1 shows the largest Brazilian producers of costume jewelry, with Sobral featuring prominently.

According to 2009 estimates issued by IBGM (Brazilian Institute of Gems and Metals), the market worldwide is worth US\$1 billion. In addition, according to the Institute, sales increased for most companies during the period 2005-2009. In the case of businesses in this sector, sales increased for $37 \%$ and remained stable for $19 \%$. Brazilian producers of costume jewelry tend to cater mainly

\footnotetext{
${ }^{1}$ De Negri, J. and Araújo, B. (2006). As empresas brasileiras e o comércio internacional. Brasília: IPEA.

${ }^{2}$ Both figures are from Machado, S. (coord.) (2003). Relatório Técnico $N^{o} 68$ 269, Final Volume 1/5. São Paulo: IPT/DEES.

${ }^{3}$ Albuquerque, E. (2001). Beleza imune a crises. Online magazine Pequenas Empresas Grandes Negócios, 154 , Nov. Retrieved from: http://revistapegn.globo.com/Empresasenegocios/0,19125,ERA455186-2481,00.html. Accessed January 20,2010
} 
for the domestic market ${ }^{4}$. However, the launch of an export assistance program in 2005 boosted exports significantly. The 2008 economic crisis harmed sales, but clear signs of a recovery have been evident since 2010. The table in Exhibit 2 shows the countries that import most costume jewelry from Brazil

There are three main production centers of costume jewelry in Brazil: Limeira (in the State of São Paulo) has 450 production firms, Guaporé (state of Rio Grande do Sul) has 160 firms, and Juazeiro do Norte (State of Ceará) has 40 firms. In addition to these firms, there are also around 700 other companies, scattered throughout Minas Gerais State. In Rio de Janeiro there are around 120 producers of jewelry and costume jewels, of which around $20 \%$ are stated to be specialized only in costume jewels; however, given the informal nature of the industry, the real number may be much higher. The revenue for the industry in Brazil was around BRL 1 billion, exports came to around USD 17 million and sales grew by around 10\% a year between 2008 and $2011^{5}$.

The costume jewelry industry is highly informal and employs many casual workers. Throughout Brazil, there are three thousand businesses, (formal and informal), of which $85 \%$ are micro businesses or small businesses ${ }^{6}$. Many of them began in the home of the artist.

The concept of fashion is constantly changing - fashion dictates concepts of beauty that can change drastically from one collection to the next. Colors are the first resources available that can achieve a visual impact, arouse the interest of the eye and draw one's attention. The notion of beauty/harmony versus ugliness /discord is subjective, since the idea is related to the concept of art. But harmony and balance are not necessarily synonymous with high costs.

In this context, aesthetic concerns are, increasingly guiding product development; however, the aesthetic appeal of the models is subject to frequent changes and can lead to obsolescence. At the same time, the importance of the design per se is increasing, and seeking to become harmonized with the human environment; this applies to the entire period from the conception and creation of everyday objects to urban planning. In addition, there is a desire to preserve the concept of the collection or trend in all the products.

\section{Information about the firm}

The firm produces costume jewelry, jewelry supplies, gift items and a wide range of decorative products using resin as a raw material. Sobral decided to baptize his company with his own surname, in the same way as other brands that were named after (what are today) consecrated founders, e.g. Valentino, Chanel, Gucci, Dolce \& Gabbana, H. Stern, and Christian Dior. Establishments identified with the owner's name seek to incorporate the meaning of his/her characteristics and attributes, as well as influencing the personal relationships that he/she maintains with the community. Through a close coexistence, the owner comes to understand the day-to-day life of each member of the company, and understand their needs and desires. Perhaps this is part of the secret of the owner's success.

\footnotetext{
${ }^{4}$ IBGM - Instituto Brasileiro de Gemas e Metais (2011). Exportação Brasileira do Capítulo 71 da NCM. Retrieved from: http://www.ibgm.com.br/admin/_upload/estatistica/arquivo/604-PaisesDest_Bijuterias_2009_2010_2011.pdf. Accessed September 13, 2012.

${ }^{5}$ Moraes, H. (2012). Mercado de fabricação de bijuterias cresce e se destaca na economia. O Fluminense, $05 / \mathrm{Feb} / 2012$. Retrieved from: http://jornal.ofluminense.com.br/editorias/empregos-e-negocios/mercado-de-fabricacao-de-bijuteriasem-alta. Accessed October 29, 2012.

${ }^{6}$ IBGM - Instituto Brasileiro de Gemas e Metais (2010). Retrieved from http://www.ibgm.com.br. Accessed January 10, 2010 .
} 
Sobral has no formal organization chart. As his is a creative company, Sobral says he is open to suggestions and that the difference in his creative approach is the absence of an ownership of ideas, a very common feature in the fashion world. As a result, he believes people in his organization work in a laid-back environment, where new ideas are welcome.

The organizational structure is quite simple. Carlos Sobral is responsible for all aspects of product design, while the administrative and financial area are managed by his son, Sobral's only partner. In early 2010, the factory, which is located in Nova Iguaçu in the state of Rio de Janeiro, had approximately 180 employees. This has risen from only 60 employees in 1991, and suggests the company has expanded considerably.

The management and other staff in the stores abroad mostly comprise employees hired locally, especially in Paris, where the labor laws have to be rigorously complied with. The supervision of the Paris stores has been carried out by Sobral himself and a local partner, from the time he started in the international market. The partner is paid a commission for taking on this responsibility. In contrast, the New York and Heidelberg outlets are supervised by Sobral, through periodic visits, and an inventory control that consists of quarterly inventories conducted by a local company.

Currently, Sobral is present in the following markets in Brazil: Sao Paulo, with two stores, located in Guarulhos Airport and in the upper class Moema neighborhood; Rio de Janeiro, with six stores located in trendy Ipanema (two stores), Rio Sul Shopping Mall, Santos Dumont airport, Antonio Carlos Jobim International Airport (two stores), and the towns of Búzios and Paraty. Abroad, the company has two stores in France on Rue de Temple and on Ile St. Louis, Paris; a store in Heidelberg, Germany; and a store in New York, USA. All of them are wholly owned by the company. As well as selling through its own outlets, Sobral also exports products to distributors in nine countries. In 2011, the company still plans to open another two units: a store in Dallas, Texas; and a store in Iguatemi Shopping Mall, Sao Paulo.

Sobral admits that he followed the policy of H. Stern - a well-known Brazilian jewelry chain -, by strategically maintaining stores in airports, with the aim of promoting the brand overseas. He jokes that copying the winning strategies of entrepreneurs from other sectors is a good idea. The entrepreneur opted to target a narrow market - people who value the distinctive characteristics of Sobral's materials and his creative designs - and this positioning has yielded good results in Brazil and abroad, with the brand standing out from its competitors.

The difference in the products stems from the handling of the resin, an expertise developed by Sobral over the course of time. The entrepreneur researched techniques, material formulae, and hand polishing - and even became renowned among the Italians, who are the world experts in working with resin. Sobral has won several important design awards in Europe and is, today, a world reference in artistic production based on resin. He has been featured on the cover of an Italian trade publication Ornamenta, a sort of bible of the jewelry industry, where they ran an article dubbing Sobral as "The Master of Resin". The table in Exhibit 3 lists the major landmarks of Sobral's career.

\section{Continued international expansion}

In early 2010, Sobral felt satisfied with his success abroad and was keen to open up stores in new countries that he still longed to conquer. However, he admitted that the growth of the company meant more responsibility, and he could no longer venture out as much as before.

The era of uncommitted trial-and-error had to make way for a more structured planning 
policy. Sobral had to decide whether it was better to strengthen his position in markets where he already operated abroad (France, Germany and the US) or to embark on forays into new countries, and if so, which ones. His financial and managerial resources were limited and he still had to attend to business in Brazil.

Sobral knew that the Brazilian market could not be overlooked. On the other hand, international expansion could, per se, provide a powerful impetus to consolidation of the brand in Brazil. But again, limited resources imposed a constraint on his dreams. Sobral also recognized that there were different modes of operation from those he had already tried - from exports to local distributors, sales to multi-brand or unspecialized stores, partnerships with retail jewelers, to company-owned stores abroad - each with its benefits and drawbacks.

In sum, a wide range of decisions had to be taken. Sobral decided that this would be a year that would define the direction where the company could go forward.

\section{Suggested questions for discussion}

The following questions, albeit not an exhaustive list, can be used to guide discussion of the case study:

1. What originally drove Sobral to look outside Brazil? Do you think this is the same reason that drives most companies in their initial forays abroad?

2. Do you think the figure of the entrepreneur played a major role in expanding the company?

3. What have been the main difficulties and challenges for the company to become internationalized? How has the company overcome them? Do you agree with the company's decisions?

4. Which entry modes did the company choose to become internationalized? In your opinion, were these the most appropriate?

5. What criteria did the company adopt in choosing France as a gateway to the international market? Do you think this was the most appropriate country for the company to choose to become internationalized?

6. What should the company's main priority be? To consolidate its position in markets where it is already present (France, Germany, USA and Brazil)? Or open up new frontiers in other countries?

7. What criteria should the company take into account in choosing new countries?

8. What modes of entry should the company adopt when expanding overseas from now on? What are the advantages and disadvantages of each?

9. What could the company do to overcome its lack of resources - financial and managerial and accelerate its expansion, both internationally and in the Brazilian market? 


\section{Exhibit 1}

The largest Brazilian producers of costume jewelry

\begin{tabular}{|l||c||c|c|c||}
\hline Companies & Sobral & Rosa Guimarães & Elmo & Three Sisters \\
\hline $\begin{array}{l}\text { Year of } \\
\text { inception }\end{array}$ & 1991 & 1991 & 2000 & 1995 \\
\hline Headquarters & Rio de Janeiro, RJ & São Paulo, SP & Guapiaçu, SP & Sao Paulo, SP \\
\hline Number of staff & 60 & 2 & 8 & 5 \\
\hline $\begin{array}{l}\text { Annual gross } \\
\text { revenue (BRL, } \\
\text { as of 2000) }\end{array}$ & 1.5 million* & 190,000 & 150,000 & 140,000 \\
\hline
\end{tabular}

* Note: in 2009 Sobral grossed more than BRL 5 million.

Source: Albuquerque, E. (2001). [see footnote 3]

\section{Exhibit 2}

Destinations of Brazilian costume jewelry

\begin{tabular}{|c|c|c|c|c|c|}
\hline & \multicolumn{3}{|c|}{ US $\$, 000$} & \multirow[b]{2}{*}{$2011 / 2010$} & \multirow[b]{2}{*}{$\%$ in 2011} \\
\hline Countries & 2009 & 2010 & 2011 & & \\
\hline United States & 5,726 & 5,667 & 3,828 & $-32 \%$ & $23 \%$ \\
\hline Argentina & 1,836 & 2,112 & 2,235 & $6 \%$ & $13 \%$ \\
\hline Mexico & 868 & 1,476 & 1,062 & $-28 \%$ & $6 \%$ \\
\hline France & 1,109 & 1,085 & 931 & $-14 \%$ & $6 \%$ \\
\hline Ecuador & - & 226 & 835 & $269 \%$ & $5 \%$ \\
\hline Guatemala & 851 & 989 & 833 & $-16 \%$ & $5 \%$ \\
\hline Colombia & 516 & 397 & 800 & $102 \%$ & $5 \%$ \\
\hline Chile & - & 377 & 507 & $34 \%$ & $3 \%$ \\
\hline Italy & 639 & 596 & 464 & $-22 \%$ & $3 \%$ \\
\hline Spain & 301 & - & 434 & & $3 \%$ \\
\hline Portugal & 377 & 468 & 418 & $-11 \%$ & $2 \%$ \\
\hline Germany & 582 & 496 & 405 & $-18 \%$ & $2 \%$ \\
\hline Hong Kong & 11 & 15 & 240 & $1500 \%$ & $1 \%$ \\
\hline Panama & 150 & 139 & 230 & $65 \%$ & $1 \%$ \\
\hline Peru & 91 & 242 & 158 & $-35 \%$ & $1 \%$ \\
\hline Canada & 147 & 195 & 103 & $-47 \%$ & $1 \%$ \\
\hline Israel & 57 & 102 & 94 & $-8 \%$ & $1 \%$ \\
\hline Angola & - & 173 & 91 & $-47 \%$ & $1 \%$ \\
\hline Australia & - & 53 & 77 & $45 \%$ & $<1 \%$ \\
\hline Costa Rica & - & 73 & 72 & $-1 \%$ & $<1 \%$ \\
\hline Japan & 71 & 85 & 50 & $-41 \%$ & $<1 \%$ \\
\hline Belgium & 17 & 15 & 47 & $213 \%$ & $<1 \%$ \\
\hline United Kingdom & 595 & 222 & 34 & $-85 \%$ & $<1 \%$ \\
\hline Nigeria & - & 25 & 30 & $20 \%$ & $<1 \%$ \\
\hline Austria & 3 & 32 & 19 & $-41 \%$ & $<1 \%$ \\
\hline United Arab Emirates & 9 & 26 & 10 & $-62 \%$ & $<1 \%$ \\
\hline Saudi Arabia & - & 17 & 4 & $-76 \%$ & $<1 \%$ \\
\hline Other countries & 3,567 & 2,007 & 2,848 & $42 \%$ & \\
\hline
\end{tabular}

Source: Brazilian Ministry of Development, Industry and Foreign Trade - MDIC/SECEX/DECEX

Preparation: IBGM (http://www.ibgm.com.br/info_estatisticas.php) 
Exhibit 3

A brief historical record of the company

\begin{tabular}{|c|l|}
\hline DATE & DESCRIPTION \\
\hline 1978 & Founding of the first factory, called Genesis \\
\hline 1981 & Genesis closes down. A new company, called Memphis is opened \\
\hline 1981 & First foray into a foreign market - Trip to Paris, France \\
\hline 1982 & Second foray into a foreign market -Trip to Paris, France \\
\hline 1982 & Formation of a partnership with French wholesaler Marc Labat \\
\hline 1983 & French partner orders complete collection of products \\
\hline 1983 to 1991 & Expanding international sales, especially in France \\
\hline 1991 & Memphis became insolvent due to Chinese competition in the international market \\
\hline 1991 & Termination of partnership with Marc Labat \\
\hline 1992 to 2001 & Devoted to the domestic market and small exports to international markets \\
\hline 2001 & The first store in Paris is opened up on Rue de Temple \\
\hline 2001 to 2009 & Consolidation of the brand name and sales in foreign markets. Two more stores in Paris. \\
\hline 2009 & Opening of a store in New York, USA and another in Heidelberg, Germany \\
\hline
\end{tabular}

